\title{
THE USE OF THREE-STEP INTERVIEW TECHNIQUE ON STUDENTS' SPEAKING ABILITY
}

\author{
Ricky Aditya Pratama ${ }^{\left.a^{*}\right)}$, Abdul Rosyid ${ }^{\text {a) }}$, Entis Sutisna ${ }^{\text {a) }}$ \\ a) Universitas Pakuan, Kota Bogor, Indonesia \\ *)e-mail korespondensi: rickyaditya60@gmail.com
}

\section{Riwayat Artikel}

diterima 05 Juni 2021

direvisi 29 Juni 2021

disetujui 28 Juli 2021

\begin{abstract}
Teaching speaking is one of the important parts of foreign language learning. The ability to communicate in a foreign language is predicted as a key to the success of the learner to master English language and to his success in their real life. The fact that cannot be denied is that sometimes students feel reluctant to speak because of shyness and fear of making a mistake. Threestep Interview technique is one of the techniques from cooperative learning that has many positive effects. This research is conducted to find out the effect of using Three-Step Interview technique on students' speaking ability. It is conducted online at Pakuan University. In this research, a preexperimental method with one group pre-test and post-test is used. 30 students of the first semester of English Education Study Program, Pakuan university are taken as samples. The data are taken from pre-test and post-test. Some steps are done to analyse the data and the design of the t-test formula is applied to get the final result. Based on the data calculation, it shows the t-test value is 19.7. The results of t-test and t-table with d.f $=29$ at significant level 0.05 is 2.04 . It shows that t-test value is higher than t-table $(19.7>2.04)$. It means that the alternative hypothesis is accepted. In conclusion, there is an effect of using a three-step interview technique on students' speaking ability.
\end{abstract}

Keywords: $\quad$ Speaking skill; Three-step Interview Technique; Cooperative Learning

\section{PENGGUNAAN TEKNIK THREE-STEP INTERVIEW PADA KEMAMPUAN SISWA DALAM BERBICARA}

\begin{abstract}
Abstrak. Pengajaran Bahasa inggris adalah salah satu bagian penting dalam pembelajaran Bahasa asing. Kemampuan dalam berkomunikasi menggunakan Bahasa kedua adalah kunci sukses para siswa dalam menguasai Bahasa inggris. Fakta yang tidak bisa dibantah adalah terkadang siswa merasa sulit untuk berbicara karena malu dan takut melakukan kesalahan. Teknik Three-step Interview adalah salah satu Teknik dari Cooperative learning yang memiliki banyak efek positif. Penelitian ini dilakukan untuk mengetahui efek penggunaan teknik Three-step Interview pada kemampuan siswa dalam berbicara. Penelitian dilakukan secara daring di Universitas Pakuan. Metode pra-eksperimental dengan desain one group pre-test dan post-test digunakan dalam penelitian ini. Terdapat 30 mahasiswa semester pertama yang dijadikan sampel. Data diperoleh dari hasil pre-test dan post-test. Beberapa langkah dilakukan untuk menganalisa data dan desain dari rumus uji-t yang diaplikasikan untuk memperoleh hasil akhir. Berdasarkan perhitungan data, hasil menunjukkan nilai uji-t adalah 19.7. Hasil dari uji-t dan t-tabel dengan derajat kebebasan (df) 29 pada taraf signifikansi 0.05 adalah 2.04. Hal tersebut menunjukkan bahwa hasil uji-t lebih besar dari t-tabel (19.7>2.04). Artinya, hipotesis alternatif diterima. Kesimpulannya, penelitian ini membuktikan bahwa Teknik Three-step interview memberikan efek pada kemampuan siswa dalam berbicara.
\end{abstract}

Kata Kunci: Kemampuan berbicara; Teknik Three-step Interview; Cooperative Learning

\section{INTRODUCTION}

Teaching English gives some challenges in 21th century. Globalization becomes more well-known in this world and must be considered as the main point. One of the ways to face globalization is by learning English. Therefore, the teacher is required to be able to master the skills to teach English well. Communication also becomes a crucial part to face globalization. When somebody is able to speak English well, he or she will be seen as a competent person.

Teaching speaking is a very important part of foreign language learning. First, the ability to communicate in a second language is a key to the success of the learner to master English language and to his success in their real life (Kayi,2006). Second, the mastery of target language is shown by the ability to speak the language (Lawtie 2004 in
Defrioka. 2009:36). Speaking classroom activity can be fun if the class has a good atmosphere. According to Harmer (2016:385) "students who get on with each other, and whose English is at an appropriate level, will often participate freely and enthusiastically." It means if the teacher is able to find appropriate methods and techniques for teaching and the learning process, it will make the students more enthusiastic to participate in the speaking class. The fact that cannot be denied is that sometimes students feel reluctant to speak because of shyness and fear of making a mistake.

Based on Harmer (2016:386) "the job of the teacher is to help them to overcome any natural shyness they might feel and by making them feel good about speaking". It means teachers have to be able to find ways to make students more confident in speaking. There are some ways 
that teachers can apply in the classroom to overcome student's problems in speaking. According to Harmer (2016:386) there are several ways, such as making students feel relaxed in the classroom, matching level and task or using pairwork and groupwork. According to all considerations, teaching speaking is a crucial part of second language learning. In order to make a speaking class with a good atmosphere, the teacher has to be able to apply suitable methods and techniques in the classroom.

Three-step Interview technique is one of the techniques from cooperative learning that have many positive effects. As stated by Kagan (2009:4.24) “Three-step Interview is one of the techniques in cooperative learning, cooperative learning works in different ways to produce positive results. Three-step Interview also has the same principle with cooperative learning, there is group work".

With appropriate teaching technique, teacher will be able to enhance students speaking skills and social skills in the same time, this statement is supported by Harmer (2016:386) "Using pairwork and groupwork is so effective, group work gives everyone chance to speak - even the shy student - but it is less pressurized for many people " and "The advantages of group work is it dramatically increases the talking opportunities for individual student" Harmer (2016:182).

It means a three-step interview will increase student's speaking skills by increasing their chance to speak, so the 10 students that feel reluctant to speak, will have a chance to speak and improve their speaking skills. According to the arguments, a three-step interview is one of the techniques of cooperative learning that has many positive effects. Three-step interview not only gives positive effects on a student's speaking skills but also on their social skills that are suitable and ready to use.

\section{RESEARCH METHODOLOGY}

In this research, a pre-experimental method is applied and pre-test post-test one group design is used to conduct this research. The researcher applied this method because the researcher only gives treatment to one class. The design is taken from Sugiyono (2013:112). The research is conducted in online class via zoom. The research is conducted to the first-semester students of Pakuan University. The population is 1st semester students of Pakuan University. The first step, the researcher collects students' speaking scores by doing a pre-test and it will be compared with the post-test score. After that, he gives treatment three times using a three-step interview technique. The last step, the researcher collects students' speaking scores by doing Impromptu speaking. The result of the pretest score and the post-test is compared using the t-test formula.

Next, there are some steps to calculate the results of pre-test and post-test. The first was calculating differences which were used to determine the difference between results of pre-test and post-test. The second was calculating the mean of difference which was used to measure the average of the range. The third was calculating deviation of difference which was used to calculate the standard deviation of the two different test results. The fourth was calculating the T-test which was used to find out the effect of the two results of pre-test and post-test. The fifth was calculating the degree of freedom which was used to determine the t-table that will be compared with the t-test's calculation result. The last step was testing the hypothesis to compare the results of t-test value with t-table value based on the degree of freedom from the samples..

\section{RESEARCH FINDING}

The research was conducted to first semester students of English education study program in Pakuan University. It was started from 4th December until 30th December 2020. There are 30 students from class 1A taken as a sample for this research. The research was done online by using zoom as a platform. Speaking test was used as the instrument for pre-test and post-test. Both tests were analyzed by using the t-test formula to find out the use of the Three-step interview technique on students' speaking ability. These are the following calculations from this research.

\section{A. The Result of Pre-test and Post-test}

The data were gained by giving two tests. First, a pretest was given before a Three-step interview was applied in the classroom in order to find out the students' speaking ability. The last, post-test was given after the treatments. The following table shows the pre-test and post-test scores of students speaking ability by doing extensive speaking. The writer described the result of pre-test and post-test as follows:

TABLE 1. Frequency Distribution of Pre-test

\begin{tabular}{ccccc}
\hline $\begin{array}{c}\text { Class } \\
\text { Interval }\end{array}$ & $\begin{array}{c}\text { Class } \\
\text { Boundary }\end{array}$ & $\begin{array}{c}\text { Mid } \\
\text { point }\end{array}$ & Fabsolute & Frelative \\
\hline $30-35$ & $29,5-35,5$ & 32,5 & 4 & $13 \%$ \\
$36-41$ & $35,5-41,5$ & 38,5 & 3 & $10 \%$ \\
$42-47$ & $41,5-47,5$ & 44,5 & 7 & $23 \%$ \\
$48-53$ & $47,5-53,5$ & 50,5 & 5 & $17 \%$ \\
$54-59$ & $53,5-59,5$ & 56,5 & 5 & $17 \%$ \\
$60-65$ & $59,5-65,5$ & 82,5 & 6 & $20 \%$ \\
& Total & & $\mathrm{N}=30$ & $100 \%$ \\
\hline
\end{tabular}

TABLE 2. Frequency Distribution of Post-test

\begin{tabular}{ccccc}
\hline $\begin{array}{c}\text { Class } \\
\text { Interval }\end{array}$ & $\begin{array}{c}\text { Class } \\
\text { Boundary }\end{array}$ & $\begin{array}{c}\text { Mid } \\
\text { point }\end{array}$ & Fabsolute & Frelative \\
\hline $58-63$ & $57,5-63,5$ & 60,5 & 3 & $10 \%$ \\
$64-69$ & $63,5-69,5$ & 66,5 & 6 & $20 \%$ \\
$70-75$ & $69,5-75,5$ & 72,5 & 5 & $17 \%$ \\
$76-81$ & $75,5-81,5$ & 78,5 & 4 & $13 \%$ \\
$82-87$ & $81,5-87,5$ & 84,5 & 7 & $23 \%$ \\
$88-93$ & $87,5-93,5$ & 90,5 & 5 & $17 \%$ \\
& Total & & $\mathrm{N}=30$ & $100 \%$ \\
\hline
\end{tabular}

\section{B. Calculation the Mean of Difference $(M d)$}

After analysing the result of pre-test and post-test, the writer calculated the mean to determine the average of pretest and post-test score. The calculation of the mean is shown as follows: 


$$
\begin{aligned}
& \mathrm{Md}=\left(\sum \mathrm{d}\right) / \mathrm{n} \\
& \mathrm{Md}=833 / 30 \\
& \mathrm{Md}=27,7
\end{aligned}
$$

According to the calculation above, the calculation of the Mean $(\mathrm{Md})$ is gained by dividing the total of gain and the number of the sample. From the calculation, the $\left(\sum d\right)$ is 833 and the numbers of samples are 30 . Therefore, the result of (Md) is 27,7 .

\section{Calculation Deviation of Gain (Xd)}

After finishing calculating the mean $(\mathrm{Md})$, the writer calculated the deviation of gain to get the gap score from students' pre-test and post-test or gain (d) and mean of gain (Md). The score of deviation of gain should be calculated one by one based on the total number of samples. The example of calculating deviation of gain $(\mathrm{Xd})$ from the first student:

$$
\begin{aligned}
& X d=d-M d \\
& X d=42-27,7 \\
& X d=14,3
\end{aligned}
$$

From the calculation, it can be seen that the first student gets the deviation of gain (d) is 42 . Moreover, the mean of gain $(\mathrm{Md})$ is 27,7 . Therefore, the result of $(\mathrm{Xd})$ for the first student is 14,3 .

\section{Calculating T-test Formula}

After calculating the deviation of gain, the T-test is used to find out the t-text value. The calculation of the t-test is shown as follows:

$$
\begin{aligned}
& \mathrm{t}=\mathrm{Md} / \sqrt{ }\left(\left(\sum \mathrm{x} 2 \mathrm{~d}\right) /(\mathrm{n}(\mathrm{n}-1))\right) \\
& \mathrm{t}=27,7 / \sqrt{ }(1713 /(30(29))) \\
& \mathrm{t}=27,7 / \sqrt{ }(1713 / 870) \\
& \mathrm{t}=27,7 / \sqrt{ } 1,97 \\
& \mathrm{t}=27,7 / 1,4 \\
& \mathrm{t}=19.7
\end{aligned}
$$

\section{E. Testing Hypothesis ( $d f$ )}

Last, the writer compared the t-test value with the degree of freedom. It was used to determine whether the alternative hypothesis was accepted or rejected. The writer counted the degree of freedom (df) by reducing one number of the total sample of this research. The calculation of the degree of freedom as follows:

$$
\text { df } \quad \begin{array}{ll} 
& =\mathrm{n}-1 \\
& =30-1 \\
& =29
\end{array}
$$

\section{DISCUSSION}

Based on the calculation of the data, the mean of difference is 27.7. Then, the total of deviation of difference is 1713. Moreover, the t-test value is 19.7. Meanwhile, $t-$ table value is 2.04 at significant level 0.05 with the degree of freedom (df) 29. In this case, the t-test value is higher than the t-table value $(19.7>2.04)$. It can be assumed that the alternative hypothesis (Ha) is accepted and the null hypothesis (Ho) is rejected.

After the treatment, it shows that the Three-Step Interview gave some positive outcome. First, students feel more confident to speak. When the students were doing the post-test, they spoke more clearly and more fluently. Second, the students are more active participating in classroom activity. It is the outcome from Three-Step Interview, because during the treatment the students are obligated to speak. In conclusion, Three-Step Interview students had an effect on the students. Based on the data above, a three-step interview can help the students to enhance students' speaking skills. It is supported by Harmer (2016:386) who stated that three-step interview technique can improve students' speaking ability and social skill at the same time. This theory is accepted in the research. It can be seen from the result that the post-test score is higher than the pre-test score. The result shows the use of a three-step interview technique on students' speaking ability. In conclusion, a three-step interview can be used as an alternative technique which can give interest and enthusiasm in learning, especially in learning speaking.

\section{CONCLUSION}

After conducting the research, it can be concluded that there is an effect of Three-step interview technique on students' speaking ability. It is proved that the result of the ttest value is higher than the t-table value. T-test value is 19.7 . Moreover, the degree of freedom (df) is 29 with the table value is $2.04(19.7>2.04)$ at significant level 0.05 . It means that the alternative hypothesis (Ha) is accepted and the null hypothesis (Ho) is rejected. From the results, the three-step interview affected students' speaking ability around 90\%. As a result, a three-step interview can help the students' more active to construct critical questions and answer them correctly. It makes them active and they can contribute in the speaking class.

Unfortunately, there are several problems that the writer experienced when conducting this research online. Teachers and students are often disconnected because of the bad signal, even there are some students who accidentally leave the zoom meeting due to an unstable connection. Besides, this technique makes teaching a learning activity more interesting and fun because the teacher gives equal opportunity to all students to speak in the class. Therefore, the students can be more enthusiastic to learn in speaking class. Moreover, a three-step interview can be applied as an alternative technique in teaching speaking.

\section{SUGGESTION}

Based on the result of the study, Three-step interview gives some positive effect to students' speaking ability. Moreover, there are several suggestions that are introduced to the teacher and the next writer.

First, it is suggested for the teacher to consider the students' needs and interests before teaching. It is important 
to apply various techniques in teaching cooperative learning techniques to make students become more active. Then, the teacher should apply some techniques in teaching that can help students to feel enthusiastic in the learning process. It is one way to make students not feel bored during the learning process in the class. One of the techniques that can be used is a three-step interview. This technique is suitable and interesting to use in speaking class.

Suggestion is also for the next writer who is interested in the same technique to apply for a three-step interview as a technique teaching. They can try to apply this technique with other skills, different grades of students and with different material depending on the students' needs.

\section{REFERENCES}

Aristy, I., Hadiansyah, R., \& Apsari, Y. (2019). Using Three Step-Interview To Improve Student's Speaking Ability. PROJECT:Professional Journal of English Education, 2(2), 175-180

Azizinezhad, M., Hashemi, M., \& Darvishi, S. (2013). Application of cooperative learning in EFL classes to enhance the students' language learning. Procedia Social and Behavioral Sciences, 93, 138-141.

Baary, H. J. F. (2019). The Use of Round Robin Technique and Gallery Walk to Improve Students' Speaking Skills. A Classroom Action Research at The Third Grade of MTS Miftahul Ulum Ngemplak Mranggen Demak In The Academic Year 2018/2019. Doctoral dissertation: IAIN SALATIGA.

Brown, H D. (2004). Language assessment principles and classroom practice. NY: Pearson Education. 172.

Brown, H. D. (2007). Principles of language learning and teaching (Vol. 5). New York: Longman. 271.

Candraloka, O. R. (2016). Implementing Three Step Interview. Edulingua, 3(1).

Defrioka, A. (2009). Improving Students' Interaction in Speaking Class Through Information Gap Activities. Muhammadiyah Purwokerto University, Indonesia. $3(2)$.

Harmer, J. (2016). The practice of English language teaching. Pearson Longman. 182, 385, 386.

Kagan, S. (2009). Kagan Cooperative Learning. Kagan Publishing. 4.24, 6.38.

Kamaliah, N. (2018). Use of The Three-Step Interview Technique in Teaching ESL Speaking. English Education Journal, 9(1), 82-101.

Kayi, H. (2006). Teaching speaking: Activities to promote speaking in a second language. The Internet TESL Journal, 12 (11).

Lawtie, F. (2004). Teaching speaking skillls 2. Overcoming classroom problems. Retrieved: www. Teachingenglish.org.uk/think. Retrieved on March 10, 2014.

Lotan, R. A. (2008). Developing language and mastering content in heterogeneous classrooms. In The teacher's role in implementing cooperative learning in the classroom. Springer, Boston, pp. 184-200

Rahayu, S. (2018). The use of Inside-Outside Circle on student vocabulary mastery. English Language Education Study Program of Faculty of Teacher Training and Educational Sciences, Pakuan University, Indonesia.

Sharan, Y., \& Sharan, S. (1994). Group investigation in the cooperative classroom. Handbook of cooperative learning methods, 97-114.

Sugiyono. (2013). Metode Penelitian Kuantitatif Kualitatif dan $R \& D$. Bandung: Alfabeta. 112.

Supardi, U. S. (2013). Aplikasi statistika dalam penelitian. Jakarta: Change Publisher 